\title{
DATA ARCHITECTURE ON DIGITAL EDUCATIONAL PLATFORMS AND DATA- COMPETENCE OF TEACHERS
}

\author{
ARQUITETURA DE DADOS SOBRE PLATAFORMAS EDUCACIONAIS DIGITAIS E \\ COMPETENCIA DOS PROFESSORES
}

\author{
ARQUITECTURA DE DATOS EN PLATAFORMAS EDUCATIVAS DIGITALES Y \\ DATOS - COMPETENCIA DE LOS PROFESORES
}

Olga A. FIOFANOVA ${ }^{1}$

\begin{abstract}
The work is aimed at identifying the data architecture and structuring the types of educational data analyzed on various digital educational platforms. The article presents research materials by the method of genetic analysis of labor actions and professional tasks of a teacher, necessary for a competent organization of development based on data. Study 1 studied 25 digital educational platforms for general education from different countries, including 9 Russian (public, private, and corporate). Study 2 included the method of genetic analysis of labor actions and professional tasks of teachers for organizing the development of children based on the analysis of educational data. The results obtained make it possible to say that in the digital educational environment the range of professional tasks is expanding, and the labor actions of the teacher are transformed in the implementation of developmental activities (as a labor function) based on the analysis of educational data.
\end{abstract}

KEYWORDS: Data architecture. Analysis of educational data. Data-competence of a teacher. Developmental education. Amplification of development

RESUMO: O trabalho tem como objetivo identificar a arquitetura de dados e estruturar os tipos de dados educacionais analisados nas diversas plataformas educacionais digitais. $O$ artigo apresenta materiais de pesquisa pelo método de análise genética das ações laborais e tarefas profissionais de um professor, necessários para uma organização competente de desenvolvimento com base em dados. O Estudo 1 estudou 25 plataformas educacionais digitais para educação geral de diferentes países, incluindo 9 russas (públicas, privadas e corporativas). $O$ Estudo 2 incluiu o método de análise genética das ações laborais e tarefas profissionais dos professores para organizar o desenvolvimento das crianças com base na análise de dados educacionais. Os resultados obtidos permitem dizer que no ambiente educacional digital se amplia o leque de atribuições profissionais e se transformam as ações laborais do professor na implementação de atividades de desenvolvimento (como função laboral) a partir da análise de dados educacionais.

PALAVRAS-CHAVE: Arquitetura de dados. Análise de dados educacionais. Competência de dados de um professor. Educação para o desenvolvimento. Ampliação do desenvolvimento.

1 Russian Academy of National Economy and Public Administration under the President of the Russian Federation (RANEPA), Moscow - Russia. Doctor of Education Sciences. ORCID: https://orcid.org/0000-00033004-8067. E-mail: fiofanova.o.a@bk.ru

RPGE- Revista on line de Política e Gestão Educacional, Araraquara, v. 25, n. esp. 3, p. 1762-1778, Sep. 2021. e-ISSN: 1519-9029 DOI: https://doi.org/10.22633/rpge.v25iesp.3.15591 
RESUMEN: El trabajo tiene como objetivo identificar la arquitectura de datos y estructurar los tipos de datos educativos analizados en diversas plataformas educativas digitales. El artículo presenta materiales de investigación por el método de análisis genético de acciones laborales y tareas profesionales de un docente, necesarios para una organización competente del desarrollo basada en datos. El estudio 1 estudió 25 plataformas educativas digitales para educación general de diferentes países, incluidas 9 rusas (públicas, privadas y corporativas). El estudio 2 incluyó el método de análisis genético de las acciones laborales y tareas profesionales de los docentes para organizar el desarrollo de los niños a partir del análisis de datos educativos. Los resultados obtenidos permiten decir que en el entorno educativo digital se amplía el abanico de tareas profesionales y las acciones laborales del docente se transforman en la implementación de actividades de desarrollo (como función laboral) a partir del análisis de datos educativos.

PALABRAS CLAVE: Arquitectura de datos. Análisis de datos educativos. Competencia de datos de un maestro. Educación para el desarrollo. Amplificación del desarrollo.

\section{Introduction}

This work touches upon the dimension of education on which its developmental potential depends - the organization of the development of schoolchildren based on the analysis of educational data. According to the results of the study, the types of educational data are characterized and classified, the analysis of which is available to teachers on digital educational platforms, services and is possible to solve the problems of organizing the development of schoolchildren. In this regard, such opportunities for the analysis of educational data for the organization of development necessitate the competence of data analysis among teachers in practice. Accordingly, there is a need for a conceptual rethinking of data science in a sectoral aspect - in the field of education. Data Driven Pedagogy as a concept of pedagogical theory and the phenomenon of pedagogical practice has a history of development no more than 10 years (FIOFANOVA, 2020a). This concept allows to deepen the theory of developmental education in a new perspective (VYGOTSKY, 2004; DAVYDOV, 1996; MARGOLIS, 2020) and the practice of reflective education based on the awareness of educational results and analytics of educational data (BETELIN et al., 2020; KENNEDY; PETERS; THOMAS, 2012; FIOFANOVA, 2020b; ICEDM, 2021).

It is necessary to turn to psychology and logic in the study of developmental processes in educational conditions. Development psychology is disclosed in the theory of developmental education (VYGOTSKY, 2004; DAVYDOV, 1996; MARGOLIS, 2020) through the activity methods of education, age characteristics of the child's leading activity, the zone of the child's proximal development. Logic (content-genetic logic) in the study of the 
development of activity reveals the meaning of the reflection of activity and the methods of its implementation, the situation of the rupture of the means of activity (SHCHEDROVITSKY, 1993). "Pedagogical methods can be conditionally decomposed into pedagogical-logical" and "pedagogical-psychological" (SHCHEDROVITSKY et al., 1993; DECREE OF THE PRESIDENT OF THE RUSSIAN FEDERATION NO. 642, 2016), to be asked to students, everywhere the only "working" and effective today are not psychological or sociological and not special-subject (mathematical, physical, chemical etc.), but only logical means and methods "(Pedagogy and Logic) (SHCHEDROVITSKY et al., 1993; FIOFANOVA et al., 2020a).

In the context of the development of digital educational platforms and services for the analysis of educational data, teachers gained access to systematized educational data (data on the results of mastering educational programs, data on the personal choice of profiles, subjects, levels of difficulty, ways of solving problems etc.), which became the basis for the application of the logic of the design of educational programs from the result, the design of educational activities based on the results of the assessment of added value (MARGOLIS, 2020), as well as the basis for the reflection of educational activities and educational results organized with students. That is, in addition to psychological means and knowledge about psychological patterns of development in educational conditions, logical analysis of data in education began to be used in pedagogical activity. In the context of the interdisciplinarity of the development of scientific knowledge, the methods of data science are integrated into pedagogy, on the basis of which the methodology and technology for the analysis of educational data is developed. Based on the analysis of educational data, the teacher carries out the production of means of developmental education, upbringing (FIOFANOVA, 2020b).

Data analysis as a logical tool for organizing activities, production, human communities has become intensively used in various fields: in the information industries (ANDERSON, 2017), in business (INMON; LINSTEDT; LEVINS; 2019; DHANRAJANI, 2018), in HR / talent management (NOCKER; VANIA, 2019; SULLIVAN, 2012), as well as in the field of education (BETELIN et al., 2020; KENNEDY; PETERS; THOMAS, 2012; FIOFANOVA, 2020b). In an interdisciplinary context, data analysis becomes the subject of discussion at various international conferences (EDM, 2021; ICEDM 2021, p. 15). International Conference on Educational Data Mining, 2021; International Conference on Educational Data Mining (ICEDM, 2021). Big data is included in the group of priority technologies of the National Technology Initiative, the Strategy of Scientific and 
Technological Development of Russia (End-to-end technologies of NTI, s/d; DECREE OF THE PRESIDENT OF THE RUSSIAN FEDERATION NO. 642, 2016).

\section{Study design}

In the field of education in the context of digital transformation, the development of institutional mechanisms for assessing the quality of education, the creation of conditions for the choice of individual educational routes in the digital educational environment, the accumulation of data sets, it is necessary to investigate:

- how the logic of pedagogical activity changes during the implementation of educational programs based on the analysis of educational data;

- what types of educational data can be the basis of pedagogical actions for the organization of developmental education;

- what competencies are necessary for a teacher to analyze educational data in the implementation of developmental education;

- How can this kind of competence be included in educational and professional standards?

Research objectives: 1) to study the architecture of the analyzed data on digital educational platforms and platforms for assessing the quality of education to ensure the development of a person (schoolchildren), 2) to study what competencies in data analysis are necessary for a teacher to organize the development of schoolchildren.

Research methods included the following. The method of structural and functional analysis of digital educational platforms of general education made it possible to identify the architecture of the analyzed data, the types of data that teachers work with.

The method of interviewing teachers and the method of genetic analysis of labor actions and professional tasks of a teacher made it possible to identify changes in the logic of labor actions of teachers, a change (expansion) of the range of professional tasks of pedagogical activity in a digital educational environment, and also made it possible to systematize and designate competencies necessary for a competent organization of developmental education based on the analyzed data.

Using the first group of methods, 25 digital educational platforms of general education from different countries were studied, including 9 Russian (public, private and corporate).

Using the second group of methods, 1250 general education teachers were interviewed. Using the method of structured interviews, we studied the issues of changing 
labor actions and professional tasks of teachers for organizing the development of children based on the analysis of educational data.

\section{Results and discussion}

The results obtained make it possible to say that in the digital educational environment the range of professional tasks is expanding, and the labor actions of the teacher are transformed in the implementation of developmental activities (as a labor function) based on the analysis of the educational data of children.

Structured interview questions included:

- For the purpose of solving what professional tasks and in what pedagogical situations did you turn to digital platforms and data analytics services?

- Based on what educational data of students did you make pedagogical decisions? What kind of pedagogical decisions were they (about adjusting educational programs, teaching methods, expanding the possibilities for choosing educational trajectories, organizing a developmental situation, what else - tell us?)

- What is the sequence of your actions in working with educational data to organize the practice of child development in education?

Analysis, statistical processing and interpretation of the structured interview data revealed the following.

The range of professional tasks of teachers is expanding, in the structure of professional tasks the analytical becomes system-forming - the task of analyzing educational data for a reasonable choice of pedagogical means of organizing development, the developmental activity of a child.

Most often, teachers turn to digital educational platforms of a regional format, which are selected by participants in educational relations for the implementation of educational programs (for example: Moscow e-school, Perm e-school, Ugra e-school, Ural e-school, eschool of the Moscow region - the school portal of the Moscow region), and also to digital educational platforms of a federal scale, for example: the Russian electronic school, the electronic platform for personalized education "Sberklass", the electronic platform "Foxword". In addition, teachers use digital data analytics services using electronic platforms of regional centers for assessing the quality of education (data of subject diagnostics, data of independent quality assessment), they also use digital portals for final attestation of students in the form of data analytics for the Unified State Exam, OGE. Less often they use the 
analysis of data available on the electronic platforms of the Olympiads (All-Russian Olympiad for schoolchildren, the NTI Olympiad, the Olympiad of Megalopolises, the platforms of specialized university Olympiads: Golden Tower, Highest Sample, Conquer the Sparrow Hills, MAMI Engineering Olympiad, Kurchatovskaya Olympiad etc.).

Accordingly, teachers can formulate judgments about the types of educational data used in pedagogical analysis only based on digital educational platforms and digital data analytics services they are familiar with. After all, turning to a certain minimum of digital services for analyzing educational data for the implementation of developmental activities is not regulated by professional standards, job responsibilities, standards of the digital educational environment, and this kind of analytics has not yet become an internal cultural norm of the professional community.

Thus, it can be noted: if the federal state educational standards of general education fix the requirements for the results of mastering educational programs, then the requirements for the analytics of these results, methods of analyzing educational data reflecting the "achievement - not achievement" of educational results are in no way regulated or indicated for teachers as possible foundations of pedagogical activity and pedagogical tools for analyzing development.

When studying the transforming labor actions of teachers in digital educational environments, the answers of teachers to the question of a structured interview were analyzed: "What is the sequence of your actions in working with educational data for organizing the practice of child development in education?". Analysis and processing of data on the generalized answers of teachers made it possible to identify a sequence based on the following logic of actions: a) search for sources on data on a digital educational platform or on other digital services; b) data analysis using available methods of analysis (personal methods of mental analysis "manual" or technological analysis of data using available services on digital platforms); c) substantiation on the basis of data analysis of certain methods of pedagogical actions to organize the development of children in the conditions of the educational process.

The genesis of "new" labor actions in the labor activity of a teacher is associated with technological innovations in the form of services for collecting and storing educational data, as well as with the conditions for carrying out educational activities by means of digital educational platforms. 
Structural and functional analysis of labor actions in the analysis of educational data made it possible to identify their structure and functions, as well as designate (name) these "new" labor actions:

- engineering and design (use of digital platforms and digital data analytics services);

- analytical and methodological (application of data analysis methods);

- organizational and practical (organization of development practice) (Table 1).

Table 1 - Structural and functional analysis of professional tasks and labor actions of a teacher in the analysis of educational data

\begin{tabular}{|l|l|}
\hline $\begin{array}{l}\text { The structure of professional tasks for } \\
\text { the analysis of educational data }\end{array}$ & $\begin{array}{l}\text { The functions of labor actions for the implementation of training, } \\
\text { education, development based on the analysis of educational data }\end{array}$ \\
\hline engineering and structural & $\begin{array}{l}\text { using digital platforms and digital data analytics services as sources } \\
\text { of data on child development }\end{array}$ \\
\hline analytical and methodological & application of methods of analysis of educational data \\
\hline organizational and practical & $\begin{array}{l}\text { organization of development practices by educational tools based on } \\
\text { the analyzed educational data }\end{array}$ \\
\hline
\end{tabular}

Source: Prepared by the authors

Accordingly, the above labor actions require teachers to implement professional competencies: digital competence (competence in choosing and using a digital data analysis service from among those available in the digital technological infrastructure of education), data competence (competence in choosing and applying methods for analyzing educational data), competence organization of development by educational means (evidence development/ evidence-based education) (Table 2).

Table 2 - The structure of the teacher's competencies in the analysis of educational data for the organization of development

\begin{tabular}{|l|l|}
\hline $\begin{array}{l}\text { The structure of professional tasks for } \\
\text { the analysis of educational data }\end{array}$ & Professional competence for the implementation of professional tasks \\
\hline engineering and structural & $\begin{array}{l}\text { digital competencies (the competence of choosing and using a digital } \\
\text { data analysis service from among those available in the digital } \\
\text { technological infrastructure of education) }\end{array}$ \\
\hline analytical and methodological & $\begin{array}{l}\text { data-competence (competence in the selection and application of } \\
\text { methods for analyzing educational data) }\end{array}$ \\
\hline organizational and practical & $\begin{array}{l}\text { evidence development - competence (competence of the organization } \\
\text { of development by educational means based on data analysis) }\end{array}$ \\
\hline
\end{tabular}

Source: Prepared by the authors 
In the European model of digital competencies DigCompEdu (Fig. 1), the competence of data analysis is considered congruent with the pedagogical function - the empowerment of students (CARRETERO GOMEZ; VUORIKARI; PUNIE, 2017).

Figure 1 - DigCompEdu model

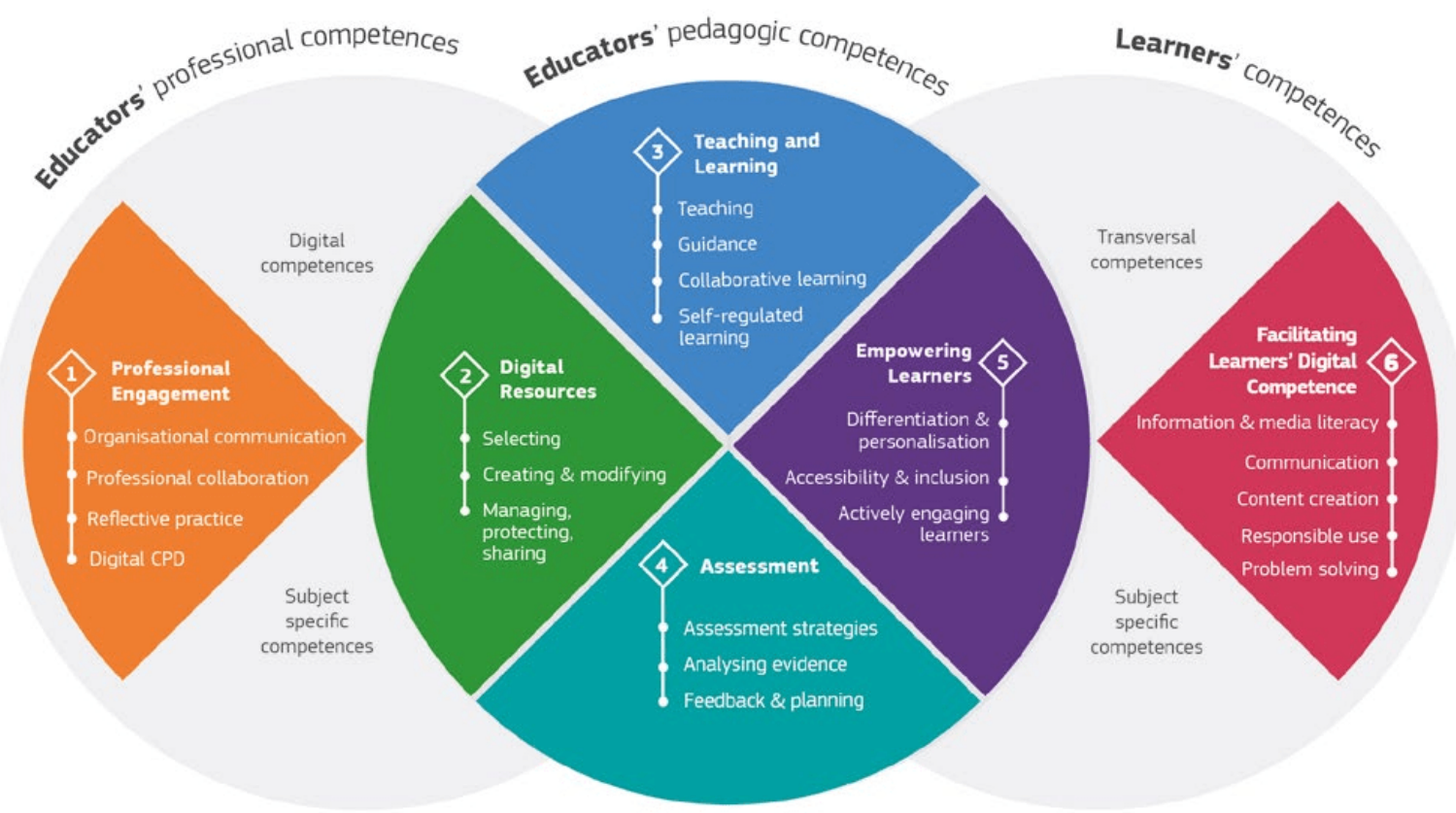

Source: Carretero Gomez, Vuorikari and Punie (2017)

The European Qualifications Framework and the National Qualifications Framework for Education in Russia are somewhat different. The competence of data analysis in the European model of competence in education is considered in the structure of the digital competence of the teacher and separately from the subject competence, but with a related common function - the empowerment of students. In Russian educational practice in the context of the institutionalized principles of developmental education and the traditional structure of pedagogical labor functions in education: the activities of teaching, upbringing, development, "analysis of educational data" as a professional task is included in the implementation of these three labor functions of a teacher. And it can also be implemented, along with the digital competencies of the teacher, both the competence of the analysis of educational data, and in the structure of subject competence - when the content of education in a subject is designed on the basis of data on the development of various industries in the context of the academic subject (but such an approach to constructing the content of education is possible only in the model of project-oriented education). 
The tendencies of amplification (complication, enrichment) of forms of activity with new technical means have long been the subject of attention of the entire cycle of the sciences of labor activity (ZINCHENKO; MORGUNOV, 1994). In developmental psychology, amplification mechanisms are disclosed in the works of V.P. Zinchenko.

In the context of the digital transformation of education, the emergence of new technological means of organizing developmental education, the question is raised about the need to improve the professional standard of a teacher as a response to the challenges of technological changes in education and the associated deepening of labor, the demand for new professional competencies of a teacher in developmental education.

How do educators use educational data analytics in organizing education and child development? A representation of this can be found in the study of public reports of educational organizations, reports on self-examination of educational organizations, as well as in the analytical reports of teachers on the implementation of educational programs.

In our study, the structured interview included the following question:

Based on what educational data of students did you make pedagogical decisions? What kind of pedagogical decisions were they (about adjusting educational programs, teaching methods, expanding the possibilities for choosing educational trajectories, organizing a developmental situation, what else? - tell me).

Based on the results of teachers' answers to interview questions, the following feature of working with data was revealed: if the data on educational results are low, then teachers try to compensate for the deficiencies with external resources: planning advanced training courses, searching for additional digital training simulators, transferring the problematic task to the school psychological service, and least of all based on the results of the analysis of educational data, it is planned to change the ways of organizing educational activities, adjusting educational programs, organizing the activities of participants in educational relations.

Educators characterize the types of educational data analyzed, depending on the digital educational platforms and digital data services with which they work. But the fact is that different digital educational platforms have different data architectures and imply different analytics capabilities.

Consider three types of educational data that educators deal with.

Data on educational outcomes. These are data on the results of the development of educational programs, data on subject diagnostics systematized on digital platforms of regional centers for assessing the quality of education, data on intermediate and current

RPGE- Revista on line de Política e Gestão Educacional, Araraquara, v. 25, n. esp. 3, p. 1762-1778, Sep. 2021. e-ISSN: 1519-9029 DOI: https://doi.org/10.22633/rpge.v25iesp.3.15591 
certification in subjects, data on solving educational problems with known answers (correct answers), systematized on digital educational platforms. This kind of data is represented in the data architecture of all digital educational platforms and education quality assessment platforms. This type of educational data of schoolchildren is considered by certification commissions as the results of pedagogical activities in the certification of teachers. This type of educational data is an important element of the traditional classroom education system. But this kind of data does not in any way reflect the ability to choose educational content, the method of solving the educational problem, the level of difficulty of the problem, the topic of the educational research, etc.

Data on the individual choices of children is an important element of the Pedagogy of Self-Determination as a modern model of education. The Law on Education in Russia (Article 34, Clause 3) regulates the choice and implementation of an individual curriculum. But the right of such implementation depends on the technological architecture of the digital educational platform. The Russian e-school provides a choice by ages and academic subjects, the Moscow e-school, in addition to the above, provides an opportunity to choose according to cognitive interests and over-subject topics through the "smart city school" service, the Foxword digital educational platform - on functional development tasks, Sberklass - provides a choice on the tasks of personalized development of "future skills" through the digital service "Navigator of the skills of the XXI century."

Why is it pedagogically important to design activities with choices and data on individual choices? These data are fundamental for the analysis of human development and education in the methodology of cultural-historical theory, psychology and pedagogy of development, activity pedagogy, pedagogy of self-determination.

Such pedagogy of digital educational platforms is aimed at developing in generation next its own cultural norm of managing its own education.

Regarding data architecture, two fundamentally different approaches should be noted. The education of the industrial era is a substantively organized educational material, control and analysis of data on the acquired volume of knowledge and reproductive skills. Education of the post-industrial era is a convergently organized content of education in educational content, control and analysis of data on the development of productive activities, personal choices in solving project problems.

Therefore, if earlier the carriers of the content of education were regulated in the form of textbooks included by order of the Ministry in the federal list of textbooks, now the 
Standard of the digital educational environment is required (It is necessary to develop a standard for the digital educational environment, 2021).

Currently, on different digital educational platforms, there are different opportunities for students to choose developmental services, educational content, methods of mastering educational material, which, in fact, latently creates a situation of educational inequality.

Another type of data, relatively new for pedagogy and education, but important in the postindustrial structure of education, is data on the project tasks solved by students. The activity, the result of which is this kind of data, is regulated by the federal state standards of general education - "project activity of students". The purpose of the activity is to develop in the next generation the ability to solve unsolved problems, design the future, model their future in relation to promising professions.

On what digital educational platforms can an educator work with this kind of data? Basically, these are corporate education platforms created by public corporations. For example, the digital educational platform of the Rusnano School League - Digital Nanograd, the digital educational and Olympiad platform of the NTI circle movement - NTI Olympiad, where children can not only choose or independently set a project task, but also assemble a project team on their own.

Thus, we can conclude that there is a large difference in the data architecture on digital educational platforms. The ability and skill of teachers to work with different types of educational data depends on the technological infrastructure of education, on the design features of data architecture on different digital educational platforms.

This issue concerns not only Russian digital educational platforms, but it is also typical for other countries.

Using the method of structural and functional analysis, the digital educational platforms of general education in different countries, both the aforementioned Russian and other countries digital educational platforms, were studied. For example:

- Kundelik (https://portal.kundelik.kz/ru/) (Kazakhstan)

- Nazarbayev Intellectual Schools (https://www.nis.edu.kz/) (Kazakhstan),

- SCHOOLS.BY (https://schools.by/) (Belarus)

- Pidruchnik (https://www.pidruchnyk.ua)

- Shho Dennik (http://shodennik.ua//) (Ukraine)

- EKOOL (https://ekool.eu/index_en.htm), (Estonia),

- ESIS (http://www.esis.de/) (Germany),

- Frog Education (https://www.frogeducation.com/)

RPGE- Revista on line de Política e Gestão Educacional, Araraquara, v. 25, n. esp. 3, p. 1762-1778, Sep. 2021. e-ISSN: $1519-9029$ 
- EdLounge (https://www.edlounge.com/) (UK)

- Tietlo Education Learning https://www.tieto.com/en/who-we-serve/publicsector/education/tieto-education-learning/ (Finland),

- 17zuoye https://ucenter.17zuoye.com/ (China).

The data architecture on these digital educational platforms is designed in different ways and depends on national educational ideals, educational standards, tasks of involving schoolchildren in socio-economic development projects of countries, in European countries in data architecture - data on future skills. The design of the data architecture and the choice of data collected for analytics depends on the legislation and legal regulations for working with personal data in countries, the institutional forms of functioning of digital platforms and data analysis services depend on the education management system built in countries. Personalized forms of storing educational data: personal digital portfolio, educational data in the student's personal account, convertible upon transition to the next level of education, digital certificates of educational achievements, etc. - depend on the legal regulations for working with educational data in the countries of the world, the projected mechanisms for the implementation of the lifelong learning concept, the projected mechanisms for integrating formal and non-formal education, the mechanisms of communication between education and the labor market (digital portfolio of competencies) implemented in countries.

Also, in the countries of the world, the tasks of developing the competencies of teachers in the analysis of educational data, the development of a methodology for the analysis of educational data are being solved. Educational data analysis methods are being integrated into pedagogy from data science. The application of methods for analyzing educational data depends on the goals of the analysis, the objects being analyzed and the types of educational data. In our research and development (FIOFANOVA, 2020b; 2020c), we systematized methods for analyzing educational data and developed a constructor for the development of data-competencies of teachers based on a database of educational data analysis cases. Methods for analyzing educational data include: 1) forecasting methods based on the analysis of educational data; 2) methods for identifying the structure of educational data; 3 ) methods for identifying the relationship between variables in a dataset.

The first group of methods is used, for example, to predict the Olympiad achievements based on the analysis of the data of the problems being solved; for predicting the choice of specialized education by schoolchildren based on data on pre-profile tests and participation in the competition for design and research work etc.). For example: on the digital platform of the distributed lyceum of the NRU HSE - https://www.hse.ru/secondary/distrlyceum - every year 
students participate in project sessions "Territory of samples", where they get acquainted with the faculties of the NRU HSE. The data is recorded on a digital platform and is further used by teachers and tutors to predict education profiles for the next year, as well as to predict areas of training in higher education.

The second group of methods is used, for example, to analyze the data of students with different types of learning difficulties in order to design the structure of the lesson taking into account the characteristics of students with different types of learning difficulties. For example: on the digital platform of the Moscow Center for the Quality of Education https://mcko.ru/pages/monitoring_and_diagnostics - in the "Monitoring and Diagnostics" section through the teacher's personal account, you can get acquainted with the results of independent diagnostics of students in subjects. These educational data, which are the basis for the analysis, allow the teacher to identify students with different levels of educational achievements, subject competencies. Further, when designing an electronic lesson on the platform of the Moscow Electronic School - http://mes.mosedu.ru - the teacher can develop a structure of differentiated educational tasks depending on the structure of the identified educational achievements and difficulties of schoolchildren based on the results of the structural analysis of their educational data.

The third group of methods is used to identify the relationship between variables in a dataset. For example, the relationship between the attendance of lessons, including on-line (electronic lessons), and the educational results of schoolchildren on the topics of the educational program, the relationship between the peculiarities of organizing the project activities of schoolchildren in the classroom and the results of the development of metasubject competencies following the development of educational programs. For example: on the digital educational platform "Petersburg Education" - https://petersburgedu.ru/qualification/ - the teacher has access to information about the current academic performance of students, the results of diagnostics of the quality of education in the classroom and school (through the ESIA - a unified system of identification and authentication), and also electronic versions of work programs in subjects. When analyzing the results of reading literacy diagnostics in 4 grades of two schools of the same city according to blocks of reading skills assessment: 1) orientation in the content of the text, 2) interpretation of information, 3) making value judgments, 4) creating your own texts; it turned out that in one school the results of the fourth-graders in block 4 were significantly worse. The use of analytical methods for identifying relationships between variables made it possible to identify the relationship between the features of work programs in subjects in connection with the results of the 
reading skills of schoolchildren. In particular: for a teacher whose students showed low results in block 4 "creating their own texts", the work program did not provide for an hour of project activity and did not include in the educational program ways of organizing educational activities to achieve meta-subject and personal results.

Teaching teachers the methods of analyzing educational data develops the datacompetence of teachers, allows teachers to be more aware of the planning of pedagogical activities, the organization of educational activities based on the analysis of educational data.

An analysis of the results of a structured interview of teachers allows us to conclude that teachers with developed data competencies are more effective in implementing developmental activities (as a labor function) based on the analysis of the educational data of children.

\section{Conclusion}

In conclusion, we will formulate conclusions and recommendations.

The data analyzed on digital educational platforms depends on the architecture of the digital educational platform, on the approaches on which the design of the digital educational platform is based ("industrial education" vs "post-industrial education"). The types of data that teachers use on various digital educational platforms and digital data analytics services: data on educational outcomes, data on individual elections, data on project tasks being solved. This allows us to analyze human development not only in the context of the present, but also in the context of his possible future (future oriented education) by educational means of the present.

The conclusions drawn from the analysis of educational data are valuable, at least not in themselves, but for the organization of developmental education. In connection with the development of the digital infrastructure of educational data analytics, the range of professional tasks of the teacher, the logic of organizing educational activities "from the result" is changing.

The structure of the teacher's professional tasks and labor actions in the analysis of educational data for the organization of education and development includes: engineeringconstructive (using digital platforms and digital data analytics services as sources of data on child development), analytical and methodological (using methods of analyzing educational data), organizational-practical (organization of development practice by educational means based on the analyzed educational data). 
Solving professional tasks requires the development of the relevant competencies among teachers: digital competencies (the competence of choosing and using a digital data analysis service from among those available in the digital technological infrastructure of education); data-competence (competence in choosing and applying methods for analyzing educational data); evidence development-competence (competence of the organization of development by educational means based on data analysis).

The trend of amplification of activities, including professional pedagogical activities, is associated with new technical means and technological changes in the field of education in the context of digital transformation, the development of digital educational environments.

Analysis of changes in professional tasks and labor functions of a teacher's professional activity is the basis for the modernization of professional standards.

The data analyzed on digital educational platforms for organizing the development of schoolchildren must be included in the structure of the elements of the Standard for the digital educational environment.

ACKNOWLEDGMENTS: The research was carried out with the financial support of the Russian Foundation for Basic Research (RFBR) within the framework of the scientific project No. 19-29-14016.

\section{REFERENCES}

ANDERSON, C. Analytical culture: From data collection to results. Litagent MIF, Moscow, 2017.

BETELIN, V.V.; KUSHNIRENKO, A.G.; SEMENOV, A.L.; SOPRUNOV, S.F. On digital literacy and the environments of its formation. Informatics and its applications, v. 14, n. 4, p. 100-107, 2020.

CARRETERO GOMEZ, S.; VUORIKARI, R.; PUNIE, Y. DigComp 2.1: The Digital Competence Framework for Citizens with eight proficiency levels and examples of use. Publications Office of the European Union, Luxembourg, 2017. Available: https://publications.jrc.ec.europa.eu/repository/handle/JRC106281

DAVYDOV, V.V. Theory of developmental learning. INTOR, Moscow, 1996.

Decree of the President of the Russian Federation No. 642. On the Strategy of Scientific and Technological development of the Russian Federation. December 1, 2016. Available: http://www.kremlin.ru/acts/bank/41449 
DHANRAJANI, S. Al and Analytics Accelerating Business Decisions. The new normal in Strategy and Enterprise Transformation. New Delhi: Wiley India Pvt. Ltd., 2018.

EDM 2021 22nd International Conference of Young Specialists in the field of electronic devices and materials. Altai, Russia, June 30 - July 4, 2021. Available:

https://edm.ieeesiberia.org

End-to-end technologies of NTI. National Technology Initiative, n.d. Retrieved from: https://nti2035.ru/technology/

FIOFANOVA, O.A. Analysis of the current state of research in the field of data-based education management. Values and meanings, v. 1, n. 65, p. 71-83, 2020a.

FIOFANOVA, O.A. Data-based pedagogy - a strategic direction of pedagogical education: competencies for analyzing educational data in professional and educational standards. The world of university science: culture, education, n. 9, p. 155-167, 2020b.

FIOFANOVA, O.A. Designer of competence modules of professional development programs for data experts in the field of education (Designer of competencies for data experts in education). Certificate of registration of the database (patent) 2020622411, Application No. 2020622293, November 11, 2020c.

ICEDM 2021: 15. International Conference on Educational Data Mining. London, United Kingdom, December 9-10, 2021. Available: https://waset.org/educational-data-miningconference-in-december-2021-in-london

INMON, W.H.; LINSTEDT, D.; LEVINS, M. Data Architecture: A Primer for the Data Scientist. Academic Press, Moscow, 2019.

International Conference on Educational Data Mining (EDM). Paris, France, 2021. Available: https://educationaldatamining.org/edm2021/

It is necessary to develop a standard for the digital educational environment. Analytical Center under the Government of the Russian Federation, March 3, 2021. Available:

https://ac.gov.ru/news/page/neobhodima-razrabotka-standarta-cifrovoj-obrazovatelnoj-sredy26863

KENNEDY, K.; PETERS, M.; THOMAS, M. How to use the analysis of value-added data to improve the education of schoolchildren: A guide for schools and school district leaders. HSE, Moscow, 2012.

MARGOLIS, A.A. The zone of immediate development (ZBR) and the organization of educational activities of students. Psychological science and education, v. 25, n. 4, p. 6-27, 2020.

NOCKER, M., VANIA, S. Big Data and Human Resources Management: The Rise of Talent Analytics. Social Sciences, v. 8, n. 10, p. 1-19, 2019.

SHCHEDROVITSKY, G.; ROZIN, V.; ALEKSEEV, N.; NEPOMNYASHCHAYA, N. Pedagogy and logic. Publishing house "Kastal", Moscow, 1993. 
SUllivan, J. Talent Management and Big Data Lessons. Talent Management Thought Leaderschip, November 19, 2012. Available: https://drjohnsullivan.com/uncategorized/4talent-management-and-big-data-lessons-from-the-presidential-election/

VYGOTSKY, L.S. Psychology of child development. Eksmo, Moscow, 2004.

ZINCHENKO, V.P.; MORGUNOV, E.B. A developing person: Essays of Russian psychology. Trivola, Moscow, 1994.

\section{How to reference this article}

FIOFANOVA O. A. Data architecture on digital educational platforms and data- competence of teachers. Revista on line de Política e Gestão Educacional, Araraquara, v. 25, n. esp. 3, p. $1762-1778, \quad$ Sep. 2021. e-ISSN: $1519-9029 . \quad$ DOI: https://doi.org/10.22633/rpge.v25iesp.3.15591

Submitted: $20 / 03 / 2021$

Required revisions: 05/06/2021

Approved: $12 / 07 / 2021$

Published: 01/08/2021 